\title{
Testing the Influence of Macroeconomic Environment on Microfinance Banks' Liquidity in Nigeria: A Vector Autoregressive Approach
}

\author{
Mulkat A. Yusuff \\ Department of General Studies, The Federal Polytechnic, Ilaro, P. O. Box 50, Ilaro, Ogun State, Nigeria
}

\begin{abstract}
Adequate level of liquidity is essential for microfinance banks to ensure sustainable provision of credit to less privileged members of the society that cannot access credit from conventional banking system. This study was therefore carried out to verify whether or not macroeconomic factors have impact on liquidity position of microfinance banks in Nigeria. To achieve the objective, vector autoregressive method has been adopted to analyze data on microfinance liquidity ratio, growth rate of real GDP, inflation rate and interest rate. The outcome of the study showed that the impact of macroeconomic factor on microfinance banks' liquidity is negligible and insignificant. The study concludes that the Nigerian macroeconomic environment has no influence on liquidity of microfinance banks. Nevertheless, the macroeconomic environment should always be closely monitored.
\end{abstract}

Keywords: Liquidity, Microfinance, Macroeconomic, Vector Autoregressive

DOI: $10.7176 / \mathrm{RJFA} / 10-24-13$

Publication date: December $31^{\text {st }} 2019$

\section{Introduction}

In developing countries including Nigeria, micro finance banks (MFBs) are important segment of financial industry. They provide financial services in form of loans, insurance, money transfers and savings on small scale to people who are economically handicapped and do not have access to financial services from conventional banking system. Microfinance banks (MFBs) by focusing on people with limited income enhance their capability to engage in sustainable economic activities. They therefore play a significant role in attenuating poverty.

The essential feature of microfinance banking is the ability to provide sufficient liquidity to customer at all time. An optimal level of liquidity is required for microfinance banks to be able to meet their current financial obligations as they come due without incurring unacceptable losses. Studies like Vodova (2011), Sheefeni (2016) and Assfaw (2019) have shown that bank liquidity position is influenced by bank specific variables as well as macroeconomic environment of the banks.

Over the years, many microfinance banks in Nigeria have been struggling to maintain adequate liquidity and unprecedented levels of liquidity support have also been given by the Central Bank of Nigeria (CBN). In spite of this extensive support, the country has witnessed the collapse of many microfinance banks owing to illiquidity. The question therefore is what are factors responsible for causing illiquidity in microfinance banks? could they be internal or external factors? Hence, this study aimed to investigate whether or not macroeconomic factors have influence on liquidity of microfinance banks in Nigeria.

\section{Literature Review}

Study on microfinance banks are colossal and diverse. A huge amount of these researches however had focused on the influence of macroeconomic variables on financial performance of microfinance banks. These studies vary in the choice of macroeconomic variables, the type and number of financial performance measures used. The findings therein remain divergent.

On a single country basis, Wooley (2008) examined the correlation between GDP growth and financial variables measured by operational self-sufficiency, the growth of profit margin and the growth of portfolio at risk at more than 30 days. The study found that the financial variables and GDP growth are not significantly correlated. Caro (2017) conducted similar study in Ecuador using macroeconomic variables like unemployment, inflation and foreign direct investment in addition to GDP growth. His results corroborate the findings of Wooley (2008) that macroeconomic factors have no influence on financial performance of MFIs.

The study of Doci (2017) used GDP growth inflation and interest rates and in contrast found that macroeconomic factors indeed have significant impact on gross loan portfolio performance of MFIs in Albania. Tran (2017) study of macroeconomic context and growth of MFIs equally established a link between growth of GDP and gross loan portfolio of MFIs in Vietnam. Hermanto and Astuti (2013) in their study of MFIs' financial activities in Java Indonesia found that even though, the two macroeconomic variables (GDP growth and inflation) used have no significant impact on MFIs' profitability, inflation exerts negative impact on NPL ratio of MFIs. 
Similarly, the cross-country analyses are not unanimous in their findings. Gonzalez (2007) assessed the relationship between gross national income (GNI) per capital and asset quality using data from 88 countries. The outcome of the study did not show any relationship between the variables tested. In the same vein, Muriu (2011) in a study of 32 African countries found that gross domestic product per capital and inflation have no impact on the profitability of MFIs. However, the findings of the study of 97 countries carried out by Imai et al (2011) revealed that gross domestic product and domestic credit as ratio of GDP have impact on financial performance proxy by profitability and quality of the portfolio.

In a different study, Buseretse (2014) examined the effect of liquidity on profitability of micro finance banks in Kenya. The study found that there is a weak negative relationship between liquidity (ratio of loans to deposits) and profitability (return on assets) of microfinance banks. In the same vein, Wambui \& Wanjiru (2016) investigated the effect of credit risk on corporate liquidity of deposit taking MFIs. The findings of the study indicate that credit risk is a significant influencer of corporate liquidity of deposit taking MFIs in Kenya. Janda \& Zetek (2013) analyzed the influence of macroeconomic factors on interest rates of microfinance institutions in Latin America and the Caribbean. The outcome of their study revealed that the impact of macroeconomic factors on interest rate policy depend significantly on the choice of proxy for interest rate used.

Mamati, Ayuma \& Mwrigi (2017) evaluated the effect of asset liability management on liquidity risk of microfinance banks in Kenya. The study concluded that asset liability management indeed has influence on liquidity risk of microfinance banks. Similar study was conducted by Ahmadyan \& Shahchera (2019) on Iranian banks. Their result corroborates the findings of Mamati, Ayuma \& Mwrigi (2017). Ekpete \& Iwedi (2017) assessed the financial intermediation functions of microfinance banks in Nigeria. The study revealed that although there is no long run equilibrium relationship between the variables considered, there is unidirectional causality running from real gross domestic product to microfinance bank intermediation variables.

On the contribution of microfinance to rural economic growth in Nigeria, the study of Udeh, Eneje \& Ani (2018) revealed that the contribution of microfinance activities is negative and insignificant. The same study was conducted by Nwude \& Anyalechi (2018), their results showed that although the introduction of microfinance banking have not contributed to agricultural productivity, it had assisted in increasing rural savings habit.

It is obvious from the above review that ample attention has not been given to influence of macroeconomic environment on liquidity and consequently the sustainability of microfinance banks. This perceived gap in literature is what this study hope to fill.

\section{Data Issues and Methodology}

The study uses annual time-series data spanning the period 1992 to 2017 . Data on microfinance banks liquidity ratio and real gross domestic product are sourced from the Central Bank of Nigeria Statistical Bulletin. The real interest rate and inflation rate data on the other hand came from World Bank Development Indicator (WDI) data base.

\subsection{Model Specification}

In order to investigate the effect of some macroeconomic variables on liquidity of microfinance banks in Nigeria, this study adopts the model of Sheefeni and Nyambe (2016) and the econometric model employ is specified thus:

$$
\mathrm{LTA}_{\mathrm{t}}=\beta_{0}+\beta_{1} \mathrm{INR}_{\mathrm{t}}+\beta_{2} \mathrm{INF}_{\mathrm{t}}+\beta_{3} \mathrm{GDP}_{\mathrm{t}}+\varepsilon_{\mathrm{t}}
$$

Where $\mathrm{LTA}_{t}$ denotes liquidity ratio, $\mathrm{INR}_{t}$ denotes real interest rate, $\mathrm{INF}_{\mathrm{t}}$ denotes inflation rate, $\mathrm{GDP}_{t}$ denotes growth rate of gross domestic product, $\varepsilon_{t}$ is error term, $\beta_{0}$ is intercept and $\beta_{1}, \beta_{2}, \beta_{3}$ are coefficients to be estimated.

\subsection{Procedure of Estimation}

The estimation begins with testing for presence of unit root in the individual series under consideration using Augmented Dickey-Fuller and Phillip Perron test statistic. Series with unit root are non-stationary and are incapable of producing valid inference. In the two tests, the null hypothesis of unit root is compared with alternative hypothesis of no unit root. If the calculated value is greater than the critical value, the null hypothesis of unit root is rejected. Having determined the stationary level of the series, Johansen co integration test technique is used to verify whether or not long term relationship exists amongst the series. The trace test and maximum eigenvalue test are used to establish the hypothesized existence of $r$ co integrating vector. Vector Autoregressive (VAR) is finally deployed to analyze the dynamic impact of random disturbances in macroeconomic variables on the liquidity position of microfinance bank.

\section{Presentation and Discussion of Findings \\ 4.1 Descriptive Statistics Analysis}

The outcome of the descriptive statistics analysis is presented in table 1 
Table 1. Descriptive Statistics

\begin{tabular}{|l|l|l|l|l|l|l|}
\hline Variable & Mean & Std. Dev. & Skewness & Kurtosis & Jaque-Bera & Prob.(JB) \\
\hline LTA & 34.88077 & 10.31479 & 0.621054 & 3.319161 & 1.781754 & 0.410296 \\
\hline INR & 2.493077 & 1.03849 & -0.294436 & 3.012015 & 1.325710 & 0.257524 \\
\hline LNINF & 2.681595 & 0.699375 & 0.968014 & 3.051906 & 4.063470 & 0.131108 \\
\hline GDP & 4.620358 & 3.892597 & 0.289235 & 3.664678 & 0.841127 & 0.656677 \\
\hline
\end{tabular}

\section{Source: Computed by the Author from E-View 10}

It can be seen in table 1 that all the variables exhibit perfect properties. For each of the variable, the mean is higher than the standard deviation. This indicates absence of outlier or weakness around the variable. The nonsignificance of the probability of Jarque-Bera statistic at 5\% confirm that the variables are normally distributed.

\subsection{Unit Root Test}

An essential step in empirical investigation is finding the stationary level of variables used in order to ascertain their order of integration. Table 2 depicts the results of the stationarity test conducted with Augmented DickeyFuller (ADF) test statistic and Phillip Perron (PP) test statistic.

Table 2. Unit Root Test Result

\begin{tabular}{|l|l|l|l|l|l|l|}
\hline Variable & $\begin{array}{l}\text { Model } \\
\text { Specification }\end{array}$ & ADF & PP & ADF & PP & $\begin{array}{l}\text { Order } \\
\text { Integration }\end{array}$ \\
\hline & & Level & Level & First Difference & First Difference & \\
\hline LTA & $\begin{array}{l}\text { Intercept and } \\
\text { Trend }\end{array}$ & -2.813594 & -2.813594 & $\begin{array}{l}-4.922596^{* * *} \\
(0.0032)\end{array}$ & $\begin{array}{c}-4.881701 * * * \\
(0.0035)\end{array}$ & $\mathrm{I}(1)$ \\
\hline INR & $\begin{array}{l}\text { Intercept and } \\
\text { Trend }\end{array}$ & -2.940563 & -2.927448 & $\begin{array}{c}-5.615832 * * * \\
(0.0002)\end{array}$ & $\begin{array}{c}-7.274254 * * \\
(0.0000)\end{array}$ & $\mathrm{I}(1)$ \\
\hline LnINF & $\begin{array}{l}\text { Intercept and } \\
\text { Trend }\end{array}$ & -1.989388 & -2.072892 & $\begin{array}{l}-4.837267 * * * \\
(0.0038)\end{array}$ & $\begin{array}{c}-5.347902 * * * \\
(0.0012)\end{array}$ & $\mathrm{I}(1)$ \\
\hline GDP & $\begin{array}{l}\text { Intercept and } \\
\text { Trend }\end{array}$ & -2.270422 & -2.373407 & $\begin{array}{c}-6.922209 * * * \\
(0.0000)\end{array}$ & $\begin{array}{c}-9.575847 * * * \\
(0.0000)\end{array}$ & $\mathrm{I}(1)$ \\
\hline
\end{tabular}

Note: The figures in parenthesis are p-values of MacKinnon (1996) one sided at $1 \%$ level of significance. $* * *$ denotes statistical significance at $1 \%$

From the results in table 2, the null hypothesis of the presence of unit root in all the variables could not be rejected at level. This implies that all the variables are not stationary at level. The stationary state is achieved by all the variables at first difference. Therefore, the order of integration for the variables is one.

\subsection{Co-integration Test}

The next step is to inquire the existence of long run co-movement amongst the variables. Having established that all the variables are integrated of order one, Johansen co-integration test technique was deployed for the analysis and the result is presented in table 3.

Table 3. Co integration Test Result

\begin{tabular}{|l|l|l|l|l|l|l|l|}
\hline \multicolumn{2}{|c|}{ Trace } & \multicolumn{2}{l|}{ Test } & \multicolumn{2}{l|}{ Maximum } \\
\hline $\begin{array}{l}\text { Ho: rank } \\
=\mathrm{r}\end{array}$ & $\begin{array}{l}\text { Ha: rank } \\
\mathrm{r}\end{array}$ & Statistic & $\begin{array}{l}\text { Critical Value } \\
5 \%\end{array}$ & $\begin{array}{l}\text { Ho: rank } \\
\mathrm{r}\end{array}$ & $\begin{array}{l}\text { Ha: rank } \\
=\mathrm{r}\end{array}$ & Statistic & $\begin{array}{l}\text { Critical Value } @ \\
5 \%\end{array}$ \\
\hline $\mathrm{r}=0$ & $\mathrm{r}=1$ & 53.87255 & 54.07904 & $\mathrm{r}=0$ & $\mathrm{r}=1$ & 25.27107 & 28.58808 \\
\hline $\mathrm{r}<=1$ & $\mathrm{r}=2$ & 28.60148 & 35.19275 & $\mathrm{r}<=1$ & $\mathrm{r}=2$ & 16.10691 & 22.29962 \\
\hline $\mathrm{r}<=2$ & $\mathrm{r}=3$ & 12.49457 & 20.26184 & $\mathrm{r}<=2$ & $\mathrm{r}=3$ & 10.64968 & 15.89210 \\
\hline $\mathrm{r}<=3$ & $\mathrm{r}=3$ & 1.844891 & 9.164546 & $\mathrm{r}<=3$ & $\mathrm{r}=3$ & 1.844891 & 9.164546 \\
\hline
\end{tabular}

Source Computed by the Author from E-View 10

Note: Both Trace and Maximum Eigen value tests indicate no co integration at $5 \%$ level of significance

The co integration result as displayed in table 3 shows that Trace test fail to reject the null hypothesis of no co integration because the statistic falls below the critical value at $5 \%$ level of significance. The result of no co integration is confirmed with Maximum Eigen test. The implication is that the variables do not have long run connection. The study then opted to analyze the short run dynamics by estimating the equation using Vector Autoregressive (VAR) methodology.

\subsection{Lag Length Selection}

The inference from VAR can only be valid if VAR model is correctly specified. To this end, the lag length test for the variables to be estimated in VAR was conducted. The result as depicted in table 4 indicates that the optimal lag order for the model by all the criteria is one. This implies that at lag one the variables are good in determining each other. 
Table 4. VAR Lag Order Selection Criteria

\begin{tabular}{|cllllll|}
\hline Lag & LogL & LR & FPE & AIC & SC & HQ \\
\hline 0 & -247.7769 & NA & 15215.85 & 20.98141 & 21.17775 & 21.03350 \\
1 & -222.1155 & $40.63051^{*}$ & $6971.227^{*}$ & $20.17629^{*}$ & $21.15801^{*}$ & $20.43674^{*}$ \\
2 & -206.8219 & 19.11706 & 8412.530 & 20.23516 & 22.00224 & 20.70396 \\
\hline
\end{tabular}

Source: E-View 10

* signifies lag order selected by the criterion

$\mathrm{LR}=$ sequential modified LR test statistic (each test at 5\% level)

$\mathrm{FPE}=$ Final prediction error

$\mathrm{AIC}=$ Akaike information criterion

$\mathrm{SC}=$ Schwarz information criterion

$\mathrm{HQ}=$ Hannah-Quinn information criterion

\subsection{Diagnostic Test}

Prior to impulse response functions and variance decomposition analyses, the result of VAR model estimated though not presented due to its lack of economic importance was subjected to some residual tests to be certain of the robustness of the model.

Table 5. VAR Residual Normality Test Result

\begin{tabular}{|c|c|c|c|c|}
\hline Component & Skewness & Chi-sq & $\mathrm{df}$ & Prob.* \\
\hline 1 & 0.924270 & 3.559478 & 1 & 0.0592 \\
\hline 2 & -0.256770 & 0.274712 & 1 & 0.6002 \\
\hline 3 & 0.210332 & 0.184332 & 1 & 0.6677 \\
\hline 4 & 0.414768 & 0.716803 & 1 & 0.3972 \\
\hline Joint & & 4.735326 & 4 & 0.3155 \\
\hline Component & Kurtosis & Chi-sq & $\mathrm{df}$ & Prob. \\
\hline 1 & 3.467393 & 0.227559 & 1 & 0.6333 \\
\hline 2 & 3.688009 & 0.493079 & 1 & 0.4826 \\
\hline 3 & 3.097682 & 0.009939 & 1 & 0.9206 \\
\hline 4 & 4.008575 & 1.059609 & 1 & 0.3033 \\
\hline Joint & & 1.790186 & 4 & 0.7743 \\
\hline Component & Jarque-Bera & Df & Prob. & \\
\hline 1 & 3.787037 & 2 & 0.1505 & \\
\hline 2 & 0.767792 & 2 & 0.6812 & \\
\hline 3 & 0.194271 & 2 & 0.9074 & \\
\hline 4 & 1.776412 & 2 & 0.4114 & \\
\hline Joint & 6.525512 & 8 & 0.5886 & \\
\hline
\end{tabular}


Table 6. VAR Residual Serial Correlation LM Test Result

\begin{tabular}{ccccccc}
\hline \hline \multicolumn{7}{c}{ Null hypothesis: No serial correlation at lag $h$} \\
\hline \hline Lag & LRE* stat & df & Prob. & Rao F-stat & df & Prob. \\
\hline \hline 1 & 21.30969 & 16 & 0.1669 & 1.433388 & $(16,40.4)$ & 0.1750 \\
2 & 9.880084 & 16 & 0.8728 & 0.585146 & $(16,40.4)$ & 0.8765 \\
\hline \hline
\end{tabular}

Null hypothesis: No serial correlation at lags 1 to $\mathrm{h}$

\begin{tabular}{ccccccc}
\hline \hline Lag & LRE* stat & df & Prob. & Rao F-stat & df & Prob. \\
\hline \hline 1 & 21.30969 & 16 & 0.1669 & 1.433388 & $(16,40.4)$ & 0.1750 \\
2 & 29.01134 & 32 & 0.6186 & 0.859762 & $(32,34.8)$ & 0.6655 \\
\hline \hline
\end{tabular}

Table 7. VAR Residual Heteroscedasticity Test Result

\begin{tabular}{|c|c|c|c|c|c|}
\hline \multicolumn{6}{|l|}{ Joint test: } \\
\hline Chi-sq & $\mathrm{df}$ & Prob. & & & \\
\hline 78.81453 & 80 & 0.5165 & & & \\
\hline \multicolumn{6}{|c|}{ Individual components: } \\
\hline Dependent & R-squared & $\mathrm{F}(8,16)$ & Prob. & Chi-sq(8) & Prob. \\
\hline res $1 *$ res 1 & 0.162414 & 0.387814 & 0.9115 & 4.060342 & 0.8516 \\
\hline res $2 *$ res 2 & 0.487460 & 1.902134 & 0.1303 & 12.18650 & 0.1431 \\
\hline res $3 *$ res 3 & 0.297428 & 0.846683 & 0.5771 & 7.435700 & 0.4904 \\
\hline res $4 *$ res 4 & 0.498337 & 1.986737 & 0.1154 & 12.45841 & 0.1319 \\
\hline res $2 *$ res 1 & 0.283081 & 0.789717 & 0.6191 & 7.077035 & 0.5283 \\
\hline res $3 *$ res 1 & 0.075550 & 0.163448 & 0.9930 & 1.888748 & 0.9842 \\
\hline res $3{ }^{*}$ res 2 & 0.317716 & 0.931332 & 0.5177 & 7.942908 & 0.4391 \\
\hline res $4 *$ res 1 & 0.268514 & 0.734159 & 0.6612 & 6.712842 & 0.5679 \\
\hline res $4 *$ res 2 & 0.159360 & 0.379139 & 0.9165 & 3.983993 & 0.8586 \\
\hline res $4 *$ res 3 & 0.455552 & 1.673445 & 0.1811 & 11.38880 & 0.1806 \\
\hline
\end{tabular}

\section{Source: E-View 10}

The outcome of the tests as display in tables 5, 6 and 7 indicate that the model has no problem of nonnormalcy, serial correlation and heteroscedasticity respectively.

4.6 Impulse Response Functions Analysis

The response of microfinance banks liquidity (LTA) to innovations in macroeconomic variables: real interest rate (INR), inflation (LNINF) and real gross domestic product (GDP) is shown in figure 1. 
Response to Cholesky One S.D. (d.f. adjusted) Innovations \pm 2 S.E.

Response of LTA to INR

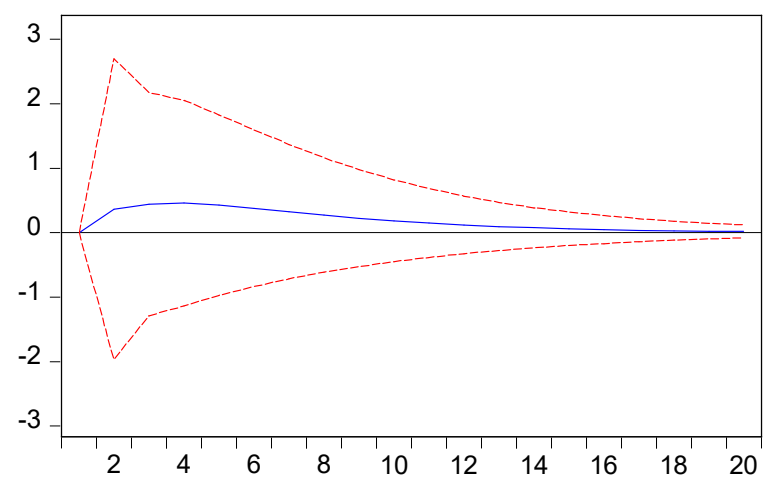

Response of LTA to LNINF



Response of LTA to GDP

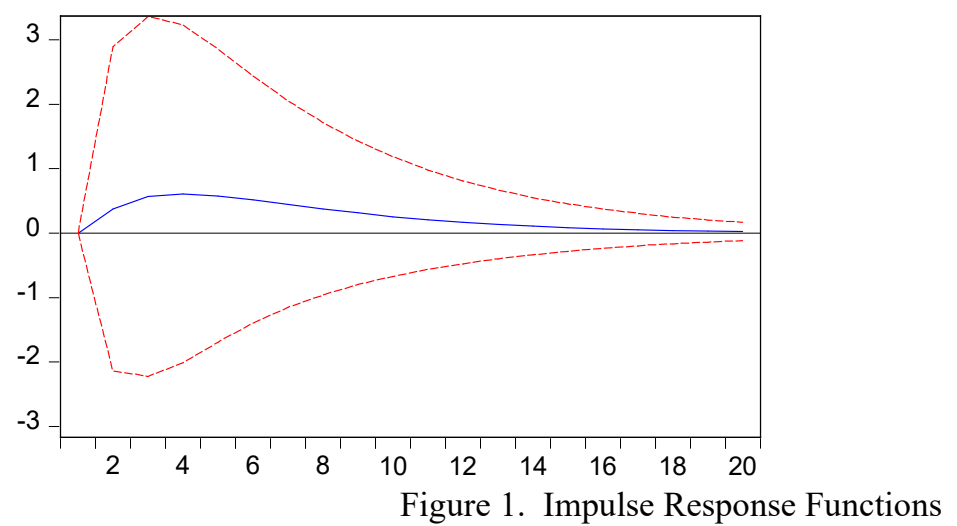

As indicated in the figure above, the effect of INR and GDP on microfinance banks liquidity are positive up till $16^{\text {th }}$ quarters and thereafter converge toward the steady state as the year progresses. Conversely, the effect of LNINF is negative also till $16^{\text {th }}$ quarters before it converges to steady state. This indicates that there is indeed a relationship between microfinance banks liquidity and macroeconomic variables in Nigeria. However, the magnitude of the relationship declines as the year advances.

\subsection{Forecast Error Decomposition}

Presented in table 8 is the result of forecast error variance decomposition of LTA over the horizon of twenty quarters. 
Table 8. Variance Decomposition

\begin{tabular}{cccccc}
\hline \hline Period & S.E. & LTA & INR & LNINF & GDP \\
\hline \hline 1 & 6.503565 & 100.0000 & 0.000000 & 0.000000 & 0.000000 \\
2 & 7.909921 & 99.34000 & 0.212476 & 0.219888 & 0.227634 \\
3 & 8.532191 & 98.19849 & 0.449402 & 0.711551 & 0.640556 \\
4 & 8.850406 & 96.98685 & 0.683835 & 1.259312 & 1.070001 \\
5 & 9.027422 & 95.91626 & 0.880843 & 1.759226 & 1.443669 \\
6 & 9.131365 & 95.06549 & 1.033072 & 2.164558 & 1.736883 \\
7 & 9.194453 & 94.43304 & 1.144092 & 2.470130 & 1.952733 \\
8 & 9.233468 & 93.98378 & 1.221911 & 2.689393 & 2.104913 \\
9 & 9.257829 & 93.67478 & 1.274917 & 2.841327 & 2.208977 \\
10 & 9.273101 & 93.46722 & 1.310264 & 2.943954 & 2.278563 \\
11 & 9.282686 & 93.33026 & 1.333460 & 3.011959 & 2.324320 \\
12 & 9.288699 & 93.24111 & 1.348495 & 3.056369 & 2.354023 \\
13 & 9.292465 & 93.18370 & 1.358147 & 3.085045 & 2.373113 \\
14 & 9.294820 & 93.14702 & 1.364297 & 3.103398 & 2.385286 \\
15 & 9.296291 & 93.12374 & 1.368191 & 3.115063 & 2.393002 \\
16 & 9.297208 & 93.10905 & 1.370646 & 3.122437 & 2.397868 \\
17 & 9.297779 & 93.09981 & 1.372188 & 3.127078 & 2.400925 \\
18 & 9.298134 & 93.09402 & 1.373154 & 3.129989 & 2.402840 \\
19 & 9.298354 & 93.09040 & 1.373756 & 3.131810 & 2.404036 \\
20 & 9.298491 & 93.08814 & 1.374132 & 3.132946 & 2.404782 \\
\hline \hline
\end{tabular}

Cholesky Ordering: LTS RINR LNINF GRG

\section{Source Computed by the Author from E-View 10}

From the result in table 8, the major source of variation in LTA is from its own shock in the first quarter. The variation ranges from 93.1 percent to 100 percent. The relative contribution of INR, LNINF and GDP start in the second quarter and increases thereafter but the fluctuation caused by these variables are not very significant. The variation caused by INR ranges between 0.21 percent in the $2^{\text {nd }}$ quarter and 1.37 percent in $20^{\text {th }}$ quarter. LNINF similarly accounts for 0.21 percent in the $2^{\text {nd }}$ quarter and 3.13 percent in the $20^{\text {th }}$ quarter. The contribution of GDP in the same vein ranges from 0.22 percent in the $2^{\text {nd }}$ quarter to 2.40 percent in $20^{\text {th }}$ quarter. Summarily, the result of forecast error variance decomposition of LTA indicates that the effect of macroeconomic variables is negligible and not statistically significant.

\section{Conclusion}

This paper assessed the link between macroeconomic variables and liquidity of microfinance banks in Nigeria. The objective is to establish whether or not macroeconomic variables affect the liquidity and consequently the survival of microfinance bank. The study was based on annual time-series data of liquidity ratio of microfinance banks, real interest rate, inflation rate and growth rate of gross domestic product. The data collected was analyzed with co integration, impulse response functions and variance decomposition. The findings of the study suggest that macroeconomic variables have insignificant impact on liquidity of microfinance banks in Nigeria. This implies that macroeconomic environment does not have significant influence on liquidity of microfinance banks in Nigeria. Nevertheless, macroeconomic environment especially inflation should be closely monitored to minimize its negative influence.

\section{References}

Ahmadyan, A. \& Shahchera, M. (2018), "Effect of Asset and Liability Management on Liquidity Risk of Iranian Banks", Journal of Money and Economy 13(1), 107-123. Retrieved from jme.mbri.ac.ir > article- $1-410$

Assfaw, A. (2019), "Firm-Specific and Macroeconomic Determinants of Banks Liquidity: Empirical Investigation from Ethiopian Private Commercial Banks", Journal of Accounting, Finance and Auditing Studies, 123-145. DOI:10.32602/jafas.2019.24

Buseretse, V. A. (2014), “The Effect of Liquidity on Profitability of Microfinance Banks in Kenya”, MSc Thesis, University of Nairobi. Retrieved from https://pdfs.semanticscholar.org >

Caro, E. J. (2017), "Effects of Macroeconomic Factors in the Performance of Microfinance Institutions in Ecuador", International Journal of Economics and Financial Issue 7(25), 547-551. Retrieved from http:www.econjournals.com 
Doci, E. (2017), "Microfinance, the Role and Impact on Macroeconomic Indicators of the Country. Case study: Albania", Mediterranean Journal of Social Sciences 8(1), 161-168. Retrieved from https://www.mcser.org> article $>$ view

Ekpete, M. S. \& Iwedi, M. (2017), "Financial Intermediation Functions of Microfinance Banks in Nigeria: A Vector Autoregressive and Multivariate Approach", International Journal of Economics and Financial Modelling 2(1), 7-24. Doi: 10.20448/811.2.7.24

Gonzalez, A. (2007), "Resilience of Microfinance Institutions to National Macroeconomic Events: An Econometric Analysis of MFI Asset Quality", MIX Discussion Paper No 1. Retrieved from https://www.ssrn.com $>$

Hermanto, B. \& Astuti, D. R. (2013), "The Impact of macroeconomic on the financial Performance of the Microfinance Institutions in Java Island, Indonesia”, Universitas Indonesia, Graduate School of Management Research Paper No. 13-08. Retrieved from https://www.ssrn.com

Imai, K. S., Gaiha, R., Thapa, G., Annim, S. K. \& Gupta, A. (2011), "Performance of Microfinance InstitutionsA Macroeconomic and Institutional Perspective", Economics Discussion Paper Series EDP-1116, The University of Manchester. Retrieved from https://ideas.repec.org > man > sespap

Janda, K. \& Zetek, P. (2013), "Macroeconomic Factors Influencing Interest Rates of Microfinance Institutions in Latin America", MPRA Paper No. 49973. Retrieved from https:/mpra.ub.uni-muenchen.de/49973/

Mamati, M. W., Ayuma, C. \& Mwrigi, P. K. (2017), "Effect of Asset Liability on Liquidity Risk of MicroFinance Banks in Kenya", International Journal of Economics, Commerce and Management 5(10), 681-729. Retrieved from ijecm.co.uk $>2017 / 10$

Muriu, P. W. (2011), "Microfinance Profitability", PhD Thesis, University of Birmingham. Retrieved from etheses, bham.ac.uk $>$ muriu 1

Nwude, E. C. \& Anyalechi, K. C. (2018), "The Impact of Microfinance on Rural Economic Growth: The Nigerian Experience", International Journal of Economics and Financial Issues 8(4), 27-31. Retrieved from https//ideas.repec.org $>2018-04-4$

Sheefeni, J. P. S. \& Nyambe, J. M. (2016), “Macroeconomic Determinants of Commercial Banks' Liquidity in Namibia", European Journal of Business, Economics and Accountancy 4(5), 19-30. Retrieved from https://www.idpublications.org>

Tran, H. T. T. (2017), "The Nexus Between the Growth of Microfinance Institutions and the Macroeconomic Context in Vietnam", Finanse Rynki Finansowe, Ubezpieczenia nr 1/2017 85, 721-730. Doi: 10.18276/frfu.2017.1.85-57

Udeh, A. I., Eneje, B. C. \& Ani, M. U. (2018), "Impact of Microfinance in Promoting Rural Economic Growth in Nigeria", International Journal of Academic Research in Economics, and Management Sciences 7(4), 167-176. Retrieved from hrmars.com>hrmars_papers

Vodova, P. (2011), "Liquidity of Czech Commercial Banks and its Determinants", International Journal of Mathematical Models and Methods in Applied Science 5, 1060-1067. Retrieved from citeseerx.ist.psu.edu > viewdoc

Wambui, M. C. \& Wanjiru, M. M. (2016), “The Effect of Credit Risk on Corporate Liquidity of Deposit Taking Microfinance Institutions", International Journal of Business and Social Science 7(4), 181-189. Retrieved from https://ijbssnet.com $>$ journals

Wooley, J. D. (2008), "Microfinance Performance and Domestic GDP Growth: Testing the Resiliency of Microfinance Institutions to Economic Change", Stanford Journal of Microfinance 1-27. Retrieved from https://www.semanticscholar.org 